\title{
ITINERARIO 1981.1
}

\section{LEYDEN CENTRE FOR THE HISTORY OF EUROPEAN EXPANSION}

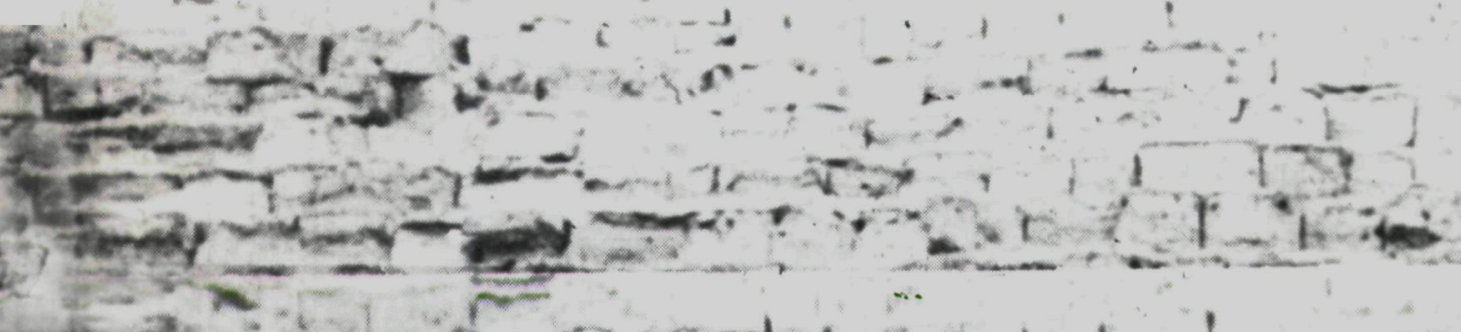
LEm

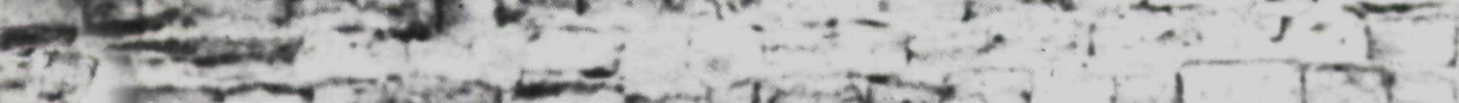
w.

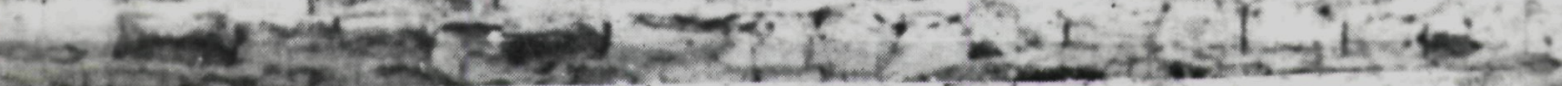

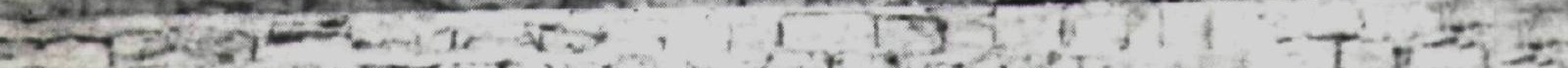

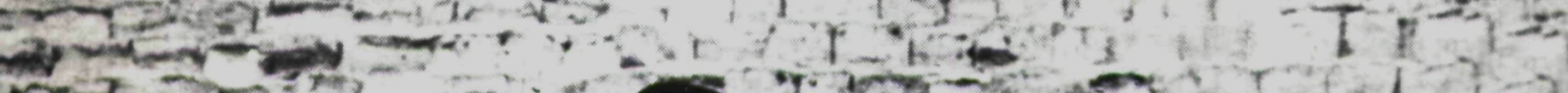

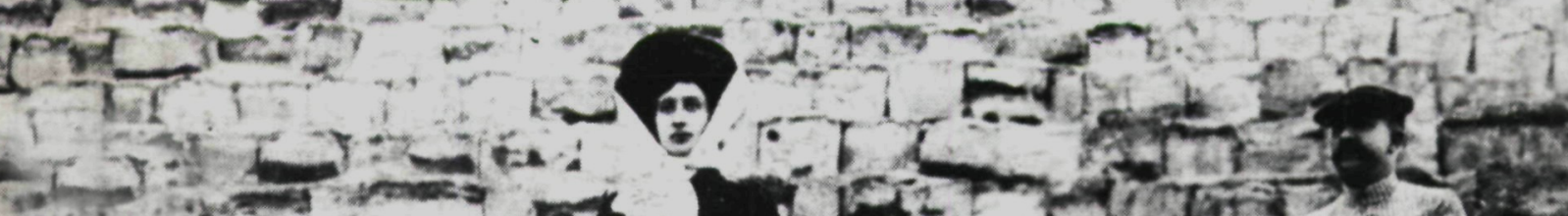

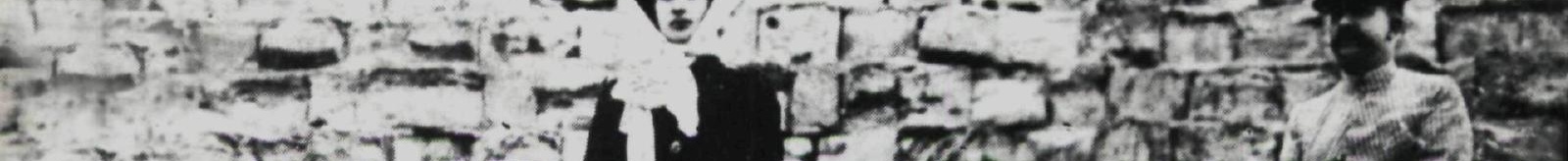

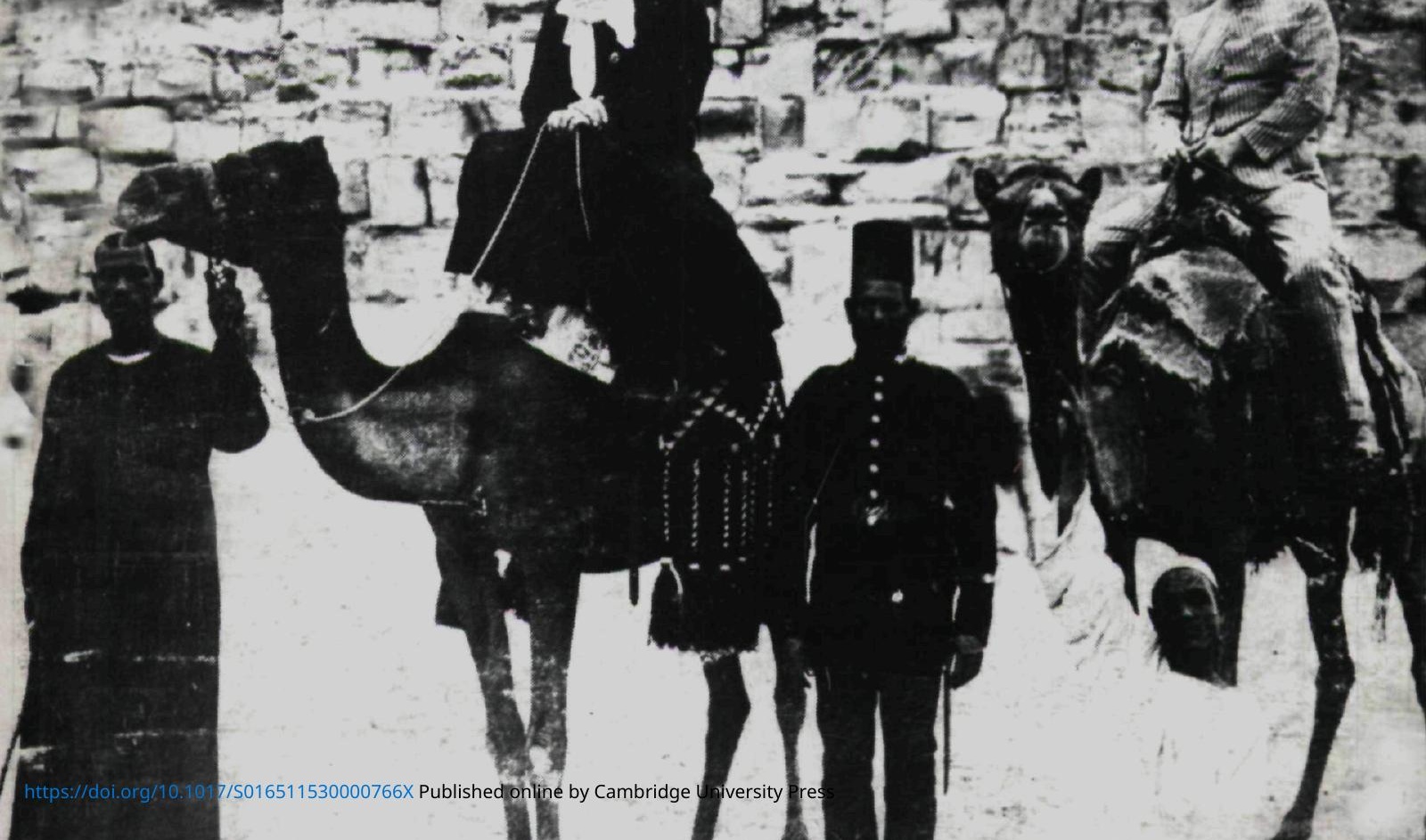




\section{ITIINERARIO}

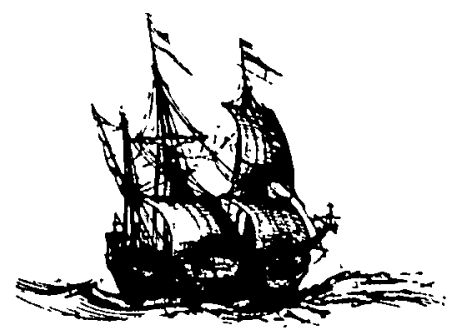

Bulletin of the Leiden Centre for the History of European Expansion 
Editors

Review Editor

Editorial Assistants

Text Composer

Consulting Editors

Corresponding Editors
George Winius \& Leonard Blussé

Gerard J.Telkamp

Jaap Valkenburg \& letje van Meurs

Mrs. M.Th. de Kock-Ververda

P.C.Emmer

F.S.Gaastra

D.H.A.Kolff

R.Ross

H.L.Wesseling

F.J.A.Broeze (Australia)

J.Stengers (Be lgium)

P.Boulle (Canada)

J. van Soest (Curaçao)

N.Steensgaard (Denmark)

C.R.Ageron \& J.-L.Miège (France) H.Bley (Germany)

C.A.Bayly \& A.T.Hopkins (Great Britain)

Om Prakash (India)

W.Remmelink (Indonesia)

A.Nagazumi (Japan)

N.Tarling (New Zealand)

A.Teixeira da Mota (Portugal)

E.Vila Vilar (Spain)

T.Abeyasinghe (Sri Lanka)

P.D.Curtin, P.E.Hoffman, G.B.Souza

\& J.E.Wills' (U.S.A.)

Itinerario is available free of charge to active researchers in the field of European expansion in exchange for articles and books they publish; all books will be reviewed. Other individuals and institutions, Am. Dollar 8 per year; quoted 'without costs to beneficiary'; institutions may arrange exchange of relevant publications.

All correspondence should be addressed to the Editors, Itinerario, Middelstegracht 4, 2312 TW Leiden, The Netherlands. 


\section{ITINERARIO, Volume 5 (1981) number 1 \\ CONTENTS}

Editorial

Letters from Readers

Lewis Hanke

F.C. van Oosten

Manuscripts invited

Plantations in Suriname

$\frac{2}{3}$

Activities of the Centre

Gerard J.Telkamp

Colonial Cities Conference

4

Pieter van Duin and

The Socio-economic History

Robert Ross of the Cape Colony

Interview

Editors

Professor Sartono Kartodirdjo

Congresses

E. van Laar

P.C.Emmer

Roger N.Buckley

Third Caribbean Archives

Conference (Nassau)

The Caribbean (Nürmberg)

UNESCO meeting of Experts

on 'the African Negro Cultural

Presence in the Caribbean and

North and South America

(Bridgetown)

G.J.Schutte

Third Dutch Indonesian

Historical Congress (Lage

George Winius

Vuursche)

Segundo Seminário Internacional

de História Indo-Portuguesa

(Lisbon)

Eighth International Economic

C.Coquery-Vidrovitch

History Congress (Budapest)

Colloque 'Entreprises et Entrepreneurs en Afrique'

Archives

Paul E.Hoffman

The Archivo de Protocolos de Sevilla

The Great Debate:

History and Underdevelopment

David S.Landes

The foundations of European Expansion and Dominion : an Equilibrium model

Articles

Jan de Vries

Roger N.Buckley

The Beginnings of Marine Archaeology in Japan Colonial Military History: A Research note 
Trends in Historiography

P.Creutzberg

The Traditional Village

Community in Java in

Transition

Hoh-cheung Mui and Lorna H.Mui

K.N.Chaudhuri, The Trading

World of Asia and the English

East India Company 1660-1760

Books

F. von Benda-Beckmann, L.Claqueur,P.C.Emmer, F.S.Gaastra, W.R.Hugenholtz, M.Kuitenbrouwer, Adriaan C. van 'Oss, M.P.H.Roessingh, H.W. van Santen, G.D.Winius.

Copyright university of Leiden 1981. ISSN 0165-1153.

Coverphoto S.Visser

\section{CENTRE FOR THE HISTORY OF EUROPEAN EXPANSION}

The Centre for the History of European Expansion, founded by the School of Humanities of Leyden University, intends to register, to coordinate, and to promote research and studies in the field of the history of European Expansion and the reactions to it.

Board: D.H.A.Kolff, chairman

J.Bruijn, C.Fasseur, H.L.Wesseling, E.Zürcher, members

All communications and inquiries may be addressed to the staff:

Dr. P.C.Emmer

Secretary of the Centre

Drs. L.Blussé

Dr. R.Ross

Drs. G.J.Telkamp Expansion history, the Americas
Expansion history, Asia Expansion history, Africa Documentation

Address: Middelstegracht 4, 2312 TW Leiden, The Netherlands Tel.: 071-148333/7180 